\title{
Persepsi Masyarakat Nelayan Dalam Menghadapi Perubahan Iklim (Ditinjau Dalam Aspek Sosial Ekonomi)
}

\author{
Mariam Ulfa* \\ * Fakultas Ilmu Sosial dan Ilmu Politik, Universitas Airlangga
}

\section{INFO ARTIKEL \\ Riwayat Artikel:}

Diterima: 24-7-2017

Disetujui: 12-11-2017

\section{Kata kunci:}

Nelayan; perubahan

iklim

\footnotetext{
Alamat Korespondensi:

Mariam Ulfa,

Fakultas Ilmu Sosial dan Ilmu Politik

Universitas Airlangga

Kampus B Dharmawangsa Dalam, Airlangga

Gubeng, Kota Surabaya, Jawa Timur 60286

E-mail: ulfamariam01@gmail.com
}

\section{ABSTRAK}

Abstrak: Perubahan iklim merupakan permasalahan utama yang dihadapi masyarakat nelayan. Fenomena perubahan iklim terjadi dikarenakan pemanasan global yang membuat suhu bumi terus meningkat dan berefek pada panjangnya musim kemarau, mencairnya gunugan es di kutub dan naiknya permukaan air laut. Desa Tamansari Kecamatan Dringu Kabupaten Probolinggo merupakan salah satu desa nelayan yang berada di pesisir pantai. Sebagai masyarakat pesisir pantai, masyarakat nelayan bergantung pada sumber daya kelautan untuk memenuhi berbagai macam kebutuhan hidup. Berdasarkan permasalahan tersebut, kemudian memunculkan permasalahan penelitian, "bagaimana masyarakat nelayan menanggapi adanya dampak perubahan iklim terhadap kehidupan sosial ekonomi”. Metode yang digunakan dalam penelitian ini adalah metode kualitatif. Peneliti bermaksud memaparkan gambaran dan data mendalam dengan menggunakan metode kualitatif melalui wawancara mendalam dan observasi. Subyek informan dalam penelitian ini adalah masyarakat nelayan desa Tamansari, untuk menentukan subyek informan dilakukan dengan cara snowball. Hasil penelitian ini mengungkapkan bahwa dampak perubahan iklim membuat nelayan mengalami permasalahan sosial ekonomi. Dalam persoalan ekonomi, dampak perubahan iklim membuat masyarakat nelayan tidak dapat memenuhi kebutuhan hidup dan rentan terhadap kemiskinan, sedangkan dalam permasalahan sosial yaitu nelayan tidak dapat menentukan musim yang terjadi karena cuaca yang tidak dapat diprediksi, jarak tempuh untuk mencari ikan lebih jauh dan sumber daya perikanan berkurang. 


\section{PENDAHULUAN}

Perubahan iklim merupakan akibat adanya pemanasan global yang memberikan dampak negatif pada wilayah pesisir terhadap aktivitas kehidupan masyarakat nelayan. Dampak negatif perubahan iklim antara lain kenaikan suhu permukaan air laut, intensitas cuaca ekstrim, perubahan pola curah hujan dan gelombang besar. Dampak negatif tersebut membawa dampak berkelanjutan dalam pola kehidupan masyarakat nelayan dalam pemenuhan kebutuhan hidup. Pemenuhan kebutuhan hidup terkait kehidupan sosial ekonominya yang bergantung pada mata pencarian pokok sebagai nelayan, sehingga masyarakat nelayan harus memiliki strategi bertahan untuk memenuhi kebutuhan hidup sehari-hari dengan modal sosial yang dimiliki.

Masyasrakat yang tinggal di wilayah pesisir merupakan masyarakat nelayan yang memiliki kehidupan ekonomi yang berkaitan dengan sumber daya laut. Kehidupan nelayan bergantung pada laut dengan ikan sebagai penghasil utama. Sebagian masyarakat di Indonesia merupakan masyarakat nelayan yang menempati wilaya-wilayah pesisir. Indonesia merupakan negara maritim yang memiliki luas wilayah perairan, dimana garis pantainya mencapai lebih dari $81.000 \mathrm{~km}$, dengan jumlah pulau mencapai lebih dari 15.500 pulau. Luas daratan mencapai 1,9 juta kilometer persegi dan luas perairan mencapai 6,6 juta kilometer persegi (Ramadhan \& Arifin, 2013;144). Wilayah perairan dan sumberdaya alamnya memiliki makna strategis bagi pengembangan ekonomi masyaraka. Berdasarkan Undang-undang Nomor 32 Tahun 2004 tentang Pemerintah Daerah, ditegaskan bahwa daerah yang memiliki wilayah laut diberikan kewenangan untuk mengelola sumberdaya di wilayah laut tersebut.

Desa-desa yang ada di Indonesia mencapai 79.075 (www.wikipedia.com) dari banyaknya desa tersebut, kurang lebih 8.090 desa digolongkan sebagai desa pesisir (Satria \& Kusumastanto, 2009;1). Sebagian besar dari masyarakat pesisir tersebut bermata pencarian sebagai nelayan. seiring berjalannya waktu kampung-kampung nelayan berkembang mengikuti garis pantai yang dimanfaatkan sebagai tempat tinggal dan membangun perekonomian. Namun dengan kekayaan alam yang melimpah, sekitar 70 persen nelayan Indonesia mengalami kemiskinan. Kemiskinan yang dialami masyarakat nelayan salah satunya merupakan dampak dari kerusakan lingkungan.

Adanya pemanasan global dan perubahan cuaca yang tidak menentu membuat nelayan tidak dapat menentukan musim datangnya ikan. Kerusakan dalam lingkungan biota laut juga membuat keberadaan ikan semakin berkurang. Kerusakan lingkungan tersebut merupakan akibat dari pengelolaan lingkungan yang tidak memadai dan dampak rumah kaca yang berdampak pada kondisi lingkungan sekitar. Tingginya pemanasan global mempengaruhi perubahan cuaca yang semakin tidak dapat ditebak.

Laporan keempat IPCC (2007) dan laporan ke lima IPCC (2013) (www.wwf.or.id) menempatkan Indonesia sebagai salah satu Negara yang rentan akibat perubahan iklim. Laporan ke lima IPCC menyatakan bahwa kawasan pesisir pantai di seluruh Asia Tenggara akan mengalami kenaikan muka air laut 10-15 persen lebih tinggi dibandingkan dengan ratarata kenaikan muka air laut global. Bencana yang terjadi akibat perubahan iklim tersebut membuat kerentanan terhadap penangkapan ikan yang dikarenakan kenaikan permukaan air laut, meningkatnya intensitas angin puting beliung tropis dan intrusi air laut.

Studi yang dilakukan oleh Helmi dan Satria mengenai strategi adaptasi nelayan terhadap perubahan ekologis menunjukkan bahwa perubahan ekologis di kawasan pesisir Pulau Panjang berpengaruh pada kehidupan nelayan dalam kehidupan sosial ekonominya (Helmi \& Satria, 2012;68-78). Kehidupan sosial ekonomi nelayan sangat ditunjang dengan kondisi iklim yang ada, sehingga adanya perubahan iklim memberikan penurunan 
pendapatan yang diperoleh nelayan untuk pemenuhan kebutuhan hidup yang membuat masyarakat nelayan berada pada ambang batas kemiskinan.

Nelayan, menurut Undang-undang perikanan nomor 45 tahun 2009, merupakan orang yang pekerjaan pokoknya melakukan penangkapan ikan. Sedangkan nelayan kecil merupakan orang yang mata pencariannya melakukan penangkapan ikan untuk memenuhi kebutuhan hidup sehari-hari. Nelayan kecil ini merupakan nelayan tradisional yang menggunakan kapal kecil dan peralatan penangkapan ikan yang sederhana. Dalam masyarakat nelayan di desa Tamansari merupakan nelayan yang tergolong tradisional, keterbatasan alat tangkap membuat nelayan memiliki kreatifitas dalam memanfaatkan bambu sebagai alat pendeteksi ikan. Telepas dari perbedaan tersebut, terjadinya perubahan iklim akibat pemanasan global sekarang ini semakin mempersulit nelayan tradisional menangkap ikan. Hal ini diperparah penggunaan bom ikan oleh nelayan-nelayan yang tidak bertanggung jawab dengan bertujuan memperoleh ikan dengan mudah. Perpaduan antara perubahan iklim dan penggunaan alat tangkap ikan yang merusak lingkungan, semakin memperparah keadaan ekosistem laut yang berimbas pada kehidupan masyarakat yang menggantungkan hidup dengan menangkap ikan.

Proses penangkapan ikan nelayan tradisional menggunakan peralatan tangkap yang sederhana. Para nelayan sangat bergantung pada musim-musim datangnya ikan dalam proses penagkapan ikan di laut. Kemunculan ikan dipengaruhi oleh faktor angin yang biasa berhembus di laut. Pada sekitar bulan September-Oktober sebagai tanda bahwa potensi sumber daya perikanan sedang baik atau musim datanngnya ikan. Namun, adanya perubahan iklim membuat nelayan mengalami kesulitan dalam menentukan musim datangnya ikan.

Perubahan iklim ini tentunya juga dialami oleh masyarakat nelayan di Probolinggo. Sampai saat ini masyarakat nelayan masih merasakan dampak perubahan iklim terhadap kegiatan mencari ikan di laut. Berbagai berita memunculkan bahwa cuaca yang buruk membuat nelayan tidak dapat melaut. Cuaca buruk terjadi pada bulan 10 tahun 2016 diketahui adanya gelombang tinggi dan terjangan ombak yang mencapai ketinggian dua meter melanda perairan laut utara Jawa Timur yang membuat aktivitas nelayan di Probolinggo terganggu. Hal ini berdasarkan data dari kantor BMKG Sidoarjo bahwa ketinggian gelombang di laut untara Jawa Timur antara 0,8 hingga 2 meter (www.m.pojokpitu.com ).

Pengaruh dampak perubahan iklim yang terjadi telah dirasakan masyarakat di seluruh penjuru bumi termasuk di Probolinggo. Setiap tahun masyarakat nelayan merasakan dampak perubahan iklim yang terjadi dan memperngaruhi perekonomian masyarakat. Dimana ketika terjadi perubahan iklim, lebih dari seratus nelayan di Probolinggo tidak berangkat melaut pada bulan Juli tahun 2015 dikarenakan adanya badai "Nangka" yaitu terjadi angin kencang dan gelombang tinggi yang terjadi di pesisir pantai PasuruanProbolinggo. Kepala Pusat Data dan Informasi BMKG menjelaskan, bahwa kencangnya angin di perairan laut Jawa akibat dampak dari degradasi tekanan udara belahan bumi bagian utara dan selatan karena badai tropis atau siklon nangka (www.beritasatu.com). Sehingga diketahui bahwa masyarakat nelayan memiliki persoalan yang kompleks dalam kehidupan sosial dan ekonomi.

Adanya perubahan iklim ini dapat menyebabkan nelayan kesulitan dalam menentukan musim penangkapan ikan karena cuaca yang tidak menentu. Hal ini beresiko mengubah stabilitas ekosistem, sosial ekonomi masyarakat dan merusak fungsi planet bumi sebagai penunjang kehidupan (Kusnadi, 2009). Sebagaimana masyarakat pada umumnya, nelayan menghadapi sejumlah masalah sosial, politik dan ekonomi dalam kehidupannya. 


\section{METODE}

Penelitian ini menggunakan metode kualitatif. Penelitian kualitatif menekankan sifat realita yang terbangun secara sosial, hubungan erat antara peneliti dan subjek yang diteliti dan tekanan situasi yang membentuk penyelidikan (Denzin \& Lincoln, 2009;6). Penelitian ini menggunakan paradigma interpretatif yang melakukan pengamatan langsung terhadap nelayan. Penelitian ini mengambil lokasi penelitian di desa Taman Sari Kecamatan Dringu Kabupaten Probolinggo. Pengambilan lokasi penelitian ini didasarkan pada karakteristik masyarakat yang sebagian besar merupakan nelayan tradisional miskin dengan keterbatasan sumberdaya baik ekonomi dan tingkat pendidikan tergolong rendah. Penelitian ini dalam menentukan subjek menggunakan snowball untuk mengidentifikasi dan mengambil informan melalui suatu relasi jaringan. Dalam penelitian ini menggunakan pengumpulan data melalui wawancara mendalam dan observasi terhadap nelayan. Sedangkan komponenkomponen analisis data menggunakan model analisis yang mencakup pemilihan data melalui wawancara mendalam dan observasi, penyajian data dan penarikan kesimpulan atau verifikasi data.

\section{Kerangka Teori}

\section{HASIL DAN PEMBAHASAN}

Hubungan antara individu dapat menjadi modal sosial yang menjadi sumber daya yang berguna bagi individu itu sendiri. Menurut Coleman, teori tindakan rasional dimulai dari kontrol atas sumber daya tertentu sehingga modal sosial merupakan jenis tertentu dari sumber daya tersebut. Modal sosial didefinisikan oleh Coleman berdasarkan fungsinya yaitu memfasilitasi pertukaran sosial sama seperti uang memfasilitasi pertukaran ekonomi (Mashud,2016). Menurut Coleman modal sosial dapat tercapai sesuai harapan dengan asumsi bahwa aktor individu biasanya mengejar kepentingan diri sendiri dan jika memilih bekerjasama karena hal tersebut menjadi kepentingannya.

Modal sosial menurut Coleman merepresentasikan sumber daya yang melibatkan harapan untuk mencapai tujuan yang melibatkan jaringan yang lebih luas yang didalam hubunganya diatur oleh tingkat kepercayaan dan nilai-nilai bersama. Modal sosial melekat pada struktur hubungan antara aktor dan antar pelaku (Coleman, 2009). Modal sosial merupakan serangkaian sumber daya yang membentuk jaringan, sumber daya tersebut merupakan modal ekonomi, modal sosial, modal budaya, nilai dan norma serta kepercayaan. Dalam studi ini, masyarakat nelayan memiliki modal sosial untuk menghadapi perubahan iklim yang memberikan dampak tehadap kehidupan sosial ekonominya. Dampak sosial yang dihadapai dengan adanya perubahan iklim, sebagaimana dalam teori modal sosial, bahwa masyarakat nelayan akan mampu mengatasi kondisinya tersebut melalaui berbagai bentuk modal sosial yang dimiliki. Melalui hubungan yang terjalin dengan baik antara nelayan dengan tetangga, teman, dan instansi pemerintah memberikan sebuah jaringan yang mampu membantu kondisi yang dihadapinya. Krisis utama yang diakibatkan oleh perubahan iklim yaitu adanya krisis ekonomi dan pengangguran, dalam artian masyarakat nelayan tidak dapat bekerja dan harus menunggu hinggga cuaca menjadi bersahabat.

Dusun Parsehan desa Tamansari merupakan salah satu desa yang berada di kecamatan Dringu, yang merupakan bagian dari wilayah Kabupaten Probolinggo, Provinsi Jawa Timur. Dusun Parsehan marupakan salah satu wilayah yang berada di pesisir pantai Probolinggo. Penduduk desa sebagian besar bermata pencaharian di sektor perikanan, yaitu sebagai nelayan. Dusun Parsehan merupakan desa Komunitas nelayan yang kehidupannya bergantung pada sumber daya kelautan.

Adanya perubahan iklim mengakibatkan nelayan tidak dapat melaut kerena terjadi badai, ombak serta angina kencang. Dampak adanya perubahan iklim juga berpengaruh pada 
pontensi sumber daya ikan yang semakin berkurang, sehingga nelayan harus mencari keberadaan ikan lebih jauh. Dampak perubahan iklim juga dapat dikatakan musim peceklik dikarenakan masyarakat nelayan tidak memperoleh penghasilan yang memadai, untuk memenuhi kebutuhan hidupnya masyarakat nelayan sangat dipengaruhi oleh lingkungan, musim dan juga pasar. Agar masyarakat nelayan tetap dapat memenuhi kebutuhan hidup dan menopang kehidupan keluarga yang mengarah pada kesejahteraan hidup maka nelayan mamanfaatkan modal sosial yang dimiliki untuk dapat mempertahankan kondisi sosial ekonominya.

\section{Dampak Perubahan Iklim Terhadap Kehidupan Sosial Nelayan}

Dampak perubahan iklim merupakan permasalahan yang dihadapi oleh nelayan. Perubahan iklim adalah fenomena global, dimana terjadi peningkatan suhu bumi sebagai akibat dari aktivitas manusia seperti penggunaan bahan bakar fosil dan perubahan dalam pemanfaatan lahan (Hukom et al. 2012;24-32). Adanya perubahan iklim mengakibatkan nelayan tidak dapat menentukan musim-musim yang akan terjadi. Setiap informan memberikan keterangan mengenai adanya perubahan iklim yang memberikan pengaruh terhadap kehidupan nelayan bahwa saat ini musim tidak dapat ditebak, sebagaimana yang diungkapkan oleh informan Mahdul, bahwa:

"wah..kalau sekarang itu musinya tidak bisa ditebak, sekarang ini musim

hujan padahal harusnya sudah mulai musim kemarau, beda dengan dulu

kalau dulu itu waktunya musim hujan ya hujan kalau kemarau ya

kemarau, sekarang malah susah ditebak"(Wawancara, tanggal 7 Maret

2017)

Keterangan informan-informan di atas terkait adanya perubahan iklim yang saat ini tidak dapat diprediksi. Ketidaktahuan masyarakat tentang perubahan prakiraan cuaca yang mengakibatkan nelayan tidak dapat menentukan musim-musim yang seharusnya terjadi. Ketika ada angin dari selatan nelayan desa Tamansari masih dapat bekerja menangkap ikan, akan tetapi jika terjadi angin dari arah barat maka nelayan tidak dapat melaut dikarenakan terjadi gelombang besar dan keberadaan ikan yang berkurang. Berikut keterangan yang diberikan informan Samiono:

"kalau angin dari selatan bisa melaut kalau angin dari barat tiak bisa

karena gelombang besar dan ikan kurang, kalau angin dari selatan tidak

ada ombak, kalau ada ombak tidak ada ikan kalau tidak ada ombak ada

ikan"(Wawancara, tanggal 7 Maret 2017)

Perubahan iklim berdampak pada kondisi cuaca yang ekstrim sehingga nelayan tidak berani untuk melaut. Perubahan iklim ini membawa dampak pada musim hujan yang lebih lama yang disertai gelombang tinggi di laut. Berdasarkan data wawancara dengan subjek bahwa ketika ada angin nelayan tidak dapat melaut, namun ketika hujan dan tanpa adanya angin, nelayan masih berani untuk melaut. Tidak hanya berdampak pada kondisi cuaca, perubahan iklim juga membuat sumber daya perikanan yang semakin berkurang. Keberadaan sumber daya perikanan yang semakin berkurang mengakibatkan nelayan harus melaut lebih jauh untuk menangkap ikan. Nelayan mencari ikan dari dusun Parsehan mencapai Paiton, lekok bahkan Panarukan, ini dlakukan nelayan dengan harapan memperoleh hasil tangkapan untuk memenuhi kebutuhan perekonomian mereka.

Nelayan dusun Parsehan terbagi menjadi 2 kelompok nelayan, yaitu nelayan ikan besar dan nelayan ikan kecil, seperti nelayan ikan layur dan nelayan yang mencari ikan shot beserta rajungan, ikan seset beserta cumi-cumi. Setiap nelayan ikan layur memilki kesamaan jam kerja dikarenakan lokasi tujuan yang sama berdasarkan keberadaan ikan, antara jam 1 atau jam 2 pagi nelayan berangkat melaut. Berbeda dengan nelayan ikan besar, nelayan yang 
mencari ikan kecil memulai pekerjaan melihat kondisi keberadaan ikan, ketika ikan berada dekat dengan tempat tinggal maka berangkat bekerja ketika menjelang subuh, sedangkan jika keberadaan ikan lebih jauh dengan tempat tinggal maka nelayan berangkat lebih pagi yaitu jam 2 dini hari.

Nelayan menempuh perjalanan yang cukup jauh untuk menangkap ikan. Proses penangkapan ikan tersebut bergantung pada kondisi keberadaan ikan, jika ikan berada di tempat yang dekat dari wilayah pemukiman maka jarak tempuh tidak terlalu jauh, namun jika ikan sulit untuk di cari dan keberadaannya jauh nelayan akan menuju pada lokasi keberadaan ikan tersebut. Mekanisme kerja masyarakat nelayan ketika terjadi perubahan iklim berpengaruh dalam waktu keberangkatan kerja, jarak yang harus ditempuh nelayan untuk menangkap ikan dikarenakan keberadaan ikan yang semakin berkurang. Jam kerja nelayan bergantung pada kondisi cuaca yang sedang terjadi, jika cuaca mendung yang disertai angin maka nelayan tidak dapat melaut.

Jam kerja nelayan juga bergantung pada kondisi keberadaan ikan, jika ada informasi mengenai keberadaan ikan yang jaraknya lebih jauh maka nelayan akan berangkat lebih awal untuk menempuh jarak tujuannya. Lokasi tujuan untuk menangkap ikan apabila tidak dipengaruhi perubahan iklim maka nelayan akan mencari ikan di lokasi yang sama dengan hari sebelumnya, namun ketika keberadaan ikan semakin berkurang dan cuaca tidak mendukung maka lokasi tujuan ditentukan berdasarkan informasi yang diperoleh dari saudara dan rekan kerja sesama nelayan. Sumber daya kelautan bukan milik perorangan maka nelayan sebagai masyarakat yang memiliki karaktersitik tempat tinggal, budaya dan pekerjaan yang sama sebagai satuan masyarakat akan memberikan informasi-informasi berkaitan dengan pekerjaannya. Nelayan tidak merasa rugi jika memberikan informasi adanya keberadaan ikan dan terlihat sebagai satuan masyarakat yang saling percaya akan rejekinya masing-masing.

Masyarakat dengan tingkat kepercayaan yang tinggi mampu menciptakan berbagai jaringan dengan baik. Sehingga dapat diketahui bahwa modal sosial akan mejadi semakin kuat jika masyarakat memiliki norma kerjasama dan saling membantu melalui ikatan jaringan yang terbentuk. Dalam masyarakat nelayan dusun Parsehan desa Tamansari adanya kepercayaan berdasarkan nilai-nilai budaya yang terbentuk. Nilai-nilai budaya tersebut membawa nelayan saling percaya terhadap masyarakat setempat yang tinggal di lingkungan pesisir pantai. Tempat tinggal merupakan salah satu faktor terbentuknya budaya serta agama yang diyakini masyarakat. Sebagai salah satu faktor dampak perubahan iklim proses kerja nelayan bergantung pada tingkat kepercayaan bahwa nelayan akan memberikan informasi keberadaan ikan dan berkumpul dalam satu tempak dengan harapan setiap nelayan memperoleh rejekinya masing-masing. Dapat diketahui bahwa kepercayaan yang terbentuk dalam masyarakat nelayan tidak lepas dari budaya dan agama sebagai kunci memperkuat kepercayaan antar masyarakat. Adanya tingkat kepercayaan yang tinggi membuat nelayan mampu menciptakan berbagai jaringan dengan baik.

Adanya kelompok masyarakat nelayan yang memiliki nilai-nilai etis bersama berdasarkan kepercayaan dan keyakinan melaui moral yang terbentuk dalam kepribadian, sehingga kelompok masyarakat nelayan desa Tamansari mewujudkan sikap saling percaya. Kepercayaan yang terbentuk tersebut mewujudkan kuatnya jaringan. Jaringan tersebut dapat digunakan nelayan untuk menanggani permasalahan dalam mekasinme kerja dalam melaut akibat adanya dampak perubahan iklim. Adanya modal sosial berupa kepercayaan mampu mempermudah proses kerja nelayan dalam melaut berupa perolehan informasi serta akses terhadap pemiliki modal yang memberikan harapan bagi masyarakat. Harapan tersebut berupa bantuan modal yang dapat digunakan nelayan untuk modal kerja dan modal memenuhi kebutuhan sehari-hari. 


\section{Dampak Perubahan Iklim Terhadap Kehidupan Ekonomi Nelayan}

Modal ekonomi yang dimiliki masyarakat nelayan tidak hanya mencakup barangbarang yang digunakan sebagai peralatan alat tangkap ikan. Modal ekonomi yang dimiliki juga mencakup pendapat yang setiap harinya diperoleh dari hasil kerja. Pendapatan tersebut digunakan untuk berbagai hal dalam mencukupi kebutuhan hidup maupun digunakan sebagai modal untuk kembali dapat bekerja. Namun ketika perubahan iklim yang membawa dampak pada perubahan cuaca yang mengakibatkan nelayan tidak dapat bekerja. Jika terjadi musim peceklik, nelayan tidak dapat bekerja bisa mencapai satu minggu. Sedangkan setiap harinya nelayan membutuhkan pengeluaran untuk memenuhi kebutuhan hidup sehari-hari, membayar hutang dan membutuhkan modal untuk bekerja.

Masyarakat nelayan bergantung pada sumber daya perikanan yang tidak pasti setiap harinya. Ketidakpastian tersebut dikarenakan nelayan harus mencari dan menangkap ikan untuk memperoleh pendapatan, berbeda dengan masyarakat petani yang memiliki lahan pertanian. Masyarakat nelayan harus mencari ikan di laut untuk memperoleh hasil penangkapan.

Pendapatan merupakan modal ekonomi masyarakat nelayan untuk memenuhi kebutuhan hidup. Pendapatan yang diperoleh akan digunakan kembali sebagai modal membeli solar, perbaikan perahu dan membeli peralatan tangkap yang rusak. Peralatan alat tangkap dan perahu merupakan sarana utama nelayan dapat bekerja menangkap ikan. Peralatan yang dimiliki nelayan sebagai modal ekonomi yang berbentuk barang digunakan untuk bekerja. Alat-alat tangkap dan perahu yang dimiliki berasal dari uang yang dimiliki nelayan dan pinjaman atau hutang pada tengkulak.

Masyarakat nelayan pada musim peceklik dihadapkan pada kondisi yang rentan terhadap kemiskinan dan kesejahteraan semakin menurun. Masyarakat nelayan mendapatkan unsur-unsur kehidupan ekonominya dari melaut yang bergantung pada penghidupan sumber daya kelautan. Kondisi serba kekurangan tidak hanya dilihat dari segi ekonomi tetapi sosial, budaya dan politik (Nugraho, 1995;31). Dalam dimensi ekonomi, kemiskinan dilihat dan menjelma dalam berbagai kebutuhan dasar manusia seperti pangan, sandang, perumahan dan kesehatan, sedangkan dalam masyarakat nelayan, kemiskinan dilihat dari kondisi kemampuan untuk memenuhi kebutuhan hidup, sandang, pangan dan kesehatan.

Kemiskinan dalam dimensi sosial budaya, tidak dapat dihitung dengan angka-angka, tetapi muncul dalam bentuk budaya kemiskinan. Dalam menyikapi hidup masyarakat miskin cenderung boros dalam membelanjakan uang, mudah putus asa, tidak berdaya dan apatis. Walaupun tidak seluruhnya benar, kondisi yang dialami masyarakat nelayan juga hampir sama seperti membelanjakan uang untuk perabotan rumah, perhiasan dan barang-barang konsumtif. Kecenderungan untuk membeli barang-barang konsumtif ketika nelayan memperoleh hasil tangkap yang cukup besar. Namun ketika musim peceklik tiba, nelayan tidak lagi memiliki tabungan untuk dapat digunakan dalam memenuhi kebutuhan hidup dan mengembangkan modal usaha.

Kemiskinan masyarakat nelayan dalam segi sosial politik yaitu munculnya kelompok masyarakat nelayan miskin dalam strukur sosial yang tidak dilibatkan dalam pengambilan keputusan. Dalam masyarakat nelayan hal ini muncul sebagai masyarakat yang termarginalisasi sehingga tidak memiliki akses seperti pemenuhan persyaratan dalam mengakses modal di lembaga keuangan seperti bank. Oleh karena itu jaringan yang terbentuk dalam masyarakat nelayan dengan tengkulak dijaga dan dipertahankan melalui kepercayaan dan nilai-nilai bersama untuk memperoleh akses modal tanpa harus melibatkan persyaratan yang lebih rumit. Nelayan cukup menjual ikan hasil tangkapnya pada tengkulak 
dan tengkulak akan memberikan modal pinjaman sebagai sarana untuk mencukupi kebutuhan hidup.

Adanya kerentanan yang dialami masyarakat nelayan karena mengalami kesulitan untuk menghadapi situasi darurat, dalam hal ini seperti yang dihadapi masyarakat nelayan desa Tamansari dengan adanya dampak perubahan iklim. Nelayan mengalami kesulitan untuk membeli bahan bakar keperluan melaut karena tidak memperoleh hasil tangkapan yang dapat dijual dan tidak ada dana cadangan yang bisa digunakan untuk keperluan mendadak, sehingga nelayan mengalami keterpurukan dalam jeratan kemiskinan. Kondisi tersebut juga diperparah keadaan nelayan dengan keterbatasan peralatan, hutang yang lebih besar dan keterbatasan nelayan dalam mengambil keputusan terhadap penentuan harga ikan. Secara umum dapat dikatakan bahwa istilah kemiskinan selalu menunjuk pada sebuah kondisi yang serba kekurangan. Kondisi serba kekurangan itu bisa saja diukur secara obyektif, dirasakan secara subyektif, atau secara relatif didasarkan pada perbandingan dengan orang lain, sehingga melahirkan pandangan obyektif, subyektif dan relatif tentang kemiskinan (Imron, 2013).

Musim peceklik mengakibatkan nelayan mengalami masa pengangguran yang beresiko terhadap kesejahteraan nelayan, jika nelayan tidak dapat bekerja maka untuk memenuhi kebutuhan hidupnya nelayan menggunakan tabungannya untuk digunakan. Ketika tabungan semakin berkurang, maka nelayan akan beralih pada bantuan orang lain dengan berhutang. Dalam hal ini nelayan membutuhkan modal sosial yang dimilikinya untuk dapat digunakan secara maksimal dengan harapan dapat mempertahankan kebutuhan ekonomi keluarga. Modal sosial memberikan harapan bagi masyarakat nelayan sebagai sumber daya yang bermanfaat dalam menghadapi perubahan iklim. Adanya modal sosial yang dimiliki masyarakat nelayan berupa jaringan, kepercayaan, norma dan nilai-nilai bersama maka akan tidak mungkin masyarakat nelayan dapat bertahan meskipun mengalami musim peceklik.

Pada saat musim peceklik, nelayan lebih memilih untuk berhutang pada tengkulak. Pinjaman modal yang diberikan tengkulak atau suplaiyer membuka modal sosial bagi nelayan untuk mengkases sumber daya yang dibutuhkan dalam menghadapi masa krisis ekonomi. Modal sosial tidak hanya dibentuk melalui interaksi nelayan pada tengkulak, tetapi interaksi balik dari tengkulak membuat hubungan tersebut memberi peluang atas penggunaan jaringan yang dimiliki.

Modal ekonomi yang dimiliki masyarakat nelayan adalah pendapatan yang diperoleh dari pekerjaan mencari ikan di laut dan alat-alat yang digunakan untuk melaut. Dapat diketahui bahwa pada masyarakat nelayan modal ekonomi yang diperoleh pada mulanya berawal dari modal budaya sebagai jembatan untuk memperoleh modal-modal lain untuk mencapai tujuan. Hubungan yang terjalin dalam masyarakat nelayan merupakan interaksi yang terjadi berdasarkan sosial dan budaya masyarakat.

\section{KESIMPULAN}

Dusun Parsehan Desa Tamansari merupakan masyarakat yang kehidupanya bergantung pada potensi sumber daya kelautan, sebagian besar masyarakat bekerja sebagai nelayan. Namun, adanya dampak perubahan iklim membawa pengaruh pada kehidupan sosial ekonomi masyarakat. Adanya perubahan iklim mengakibatkan nelayan tidak dapat menentukan musim-musim yang akan terjadi. Perubahan iklim berdampak pada kondisi cuaca yang ekstrim sehingga nelayan tidak berani untuk melaut. Tidak hanya berdampak pada kondisi cuaca, perubahan iklim juga membuat sumber daya perikanan yang semakin berkurang oleh karena itu nelayan memilih untuk mencari ikan dengan jarak yang lebih jauh. Menurut masyarakat nelayan, saat ini perubahan iklim sudah tidak dapat ditentukan dan 
diprediksi, oleh karena itu ketika terjadi mendung dan angin nelayan lebih memilih untuk tidak melaut yang dikhawatirkan akan membahayakan nelayan itu sendiri. Perubahan cuaca tersebut juga membuat nelayan berada pada musim peceklik yang rentan terhadap kemiskinan dan kesejahteraan semakin menurun. Ketika nelayan tidak memperoleh hasil tangkap, nelayan mengalami kesulitan untuk membeli bahan bakar keperluan dan tidak ada dana cadangan yang bisa digunakan untuk keperluan mendadak. Bagi masyarakat nelayan ketika terjadi perubahan iklim yang mempengaruhi kehidupan sosial ekonominya modal utama yang digunakan untuk menutupi keterbatasannya adalah jaringan. Melalui jaringan nelayan memperoleh modal pinjaman yang diperoleh dari tengkulak.

\section{DAFTAR RUJUKAN}

Coleman, James S., 2009. Social Capital In The Creation Of Human Capital. University Of Chicago Press.

Denzin, Norman K. \& Lincoln, Yvonna S., 2009. Handbook of Qualitatif Research. Yogyakarta: Pustaka Pelajar.

Field, John. 2010. Modal Sosial. Bantul: Kreasi Wacana.

Fukuyama, Francis. 2002. Trust: Kebajikan Sosial dan Penciptaan Kemakmuran. Yogyakarta: Qalam.

Helmi, Dan Satria. 2012. Strategi Adaptasi Nelayan Terhadap Perubahan Ekoligis. Jurnal: IPB. Vol 16, No. 1, Juli 2012:68-78.

Hukom dkk. 2012. Pengaruh Perubahan Iklim Terhadap Optimasi Ketersediaan Air di Irigasi Way Mital Propinsi Maluku. Jurnal Teknik Pengairan Universitas Brawijaya.

Imron, Masyhuri. 2003. Kemiskinan dalam Masyarakat Nelayan. Jurnal Masyarakat dan Budaya, Volume 5 No.1 Tahun 2003.

Kusnadi. 2000. Nelayan: Strategi Adaptasi Dan Jaringan Sosial. Bandung: Humaniora Utama Press.

.2009. Keberdayaan Nelayan \& Dinamika Ekonomi Pesisir. Yogjakarta: Lembaga Penelitian Universitas Jember Dan Ar-Ruzz Media.

Mashud, Mustain. 20016. Memahami Teori-Teori Modal Sosial. (mustain-ua.com)

Nugraho, Heru. 1995. Kemisinan, Ketimpangan, dan Pemberdayaan. Yogyakarta: Aditya Media.

Ramadhan \& Arifin, 2013. Aplikasi Sistem Informasi Geografis dalam Penilaian Proporsi Luas Laut Indonesia. Jurnal Ilmiah Geomatika Volume 19 no. 2 Desember 2013

Satria \& Kusumastanto. Strategi Pembangunan Desa Pesisir. PKSPL- IPB Press.

Undangan-Undang Republik Indonesia Nomor 45 Tahun 2009 Tentang Perikanan, Pasal 9 Ayat 1.

http://www.id.m.wikipedia.org diakses pada tanggal 17/05/2017 pukul: 13.59

http://www.researchgate.net.

http//:www.wwf.or.id , dilihat pada tanggal 25/01/2017

http://www.m.pojokpitu.com , dilihat pada tanggal 20/01/2017

http://www.beritasatu.com , dilihat pada tanggal 20/01/2017 